ENCYCLOPEDDE Encyclopédie berbère

BERBERE

13 | 1994

13 | Chèvre - Columnatien

\title{
Chiniava
}

\section{J. Peyras}

\section{OpenEdition}

Journals

Édition électronique

URL : http://journals.openedition.org/encyclopedieberbere/2241

DOI : 10.4000/encyclopedieberbere.2241

ISSN : 2262-7197

\section{Éditeur}

Peeters Publishers

\section{Édition imprimée}

Date de publication : 1 février 1994

Pagination : 1925-1926

ISBN : 2-85744-696-9

ISSN : 1015-7344

Référence électronique

J. Peyras, «Chiniava », Encyclopédie berbère [En ligne], 13 | 1994, document C56, mis en ligne le 01 mars 2012, consulté le 25 septembre 2020. URL : http://journals.openedition.org/

encyclopedieberbere/2241; DOI : https://doi.org/10.4000/encyclopedieberbere.2241

Ce document a été généré automatiquement le 25 septembre 2020

(C) Tous droits réservés 


\section{Chiniava}

\section{J. Peyras}

1 L'inscription C.25450, datable de la fin du $\mathrm{II}^{\mathrm{e}}$ siècle ou du début du $\mathrm{III}^{\mathrm{e}}$ [Peyras et Maurin, 1974] a permis de situer au cœur du Tell nord-est, sur le Henchir Guennba (At. Arch. Tun., f. Mateur, 225), l'oppidum ciuium Romanorum de Pline l'Ancien (Hist. Nat, V, 29), et d'éliminer les leçons Chimauense et Ciniauense de certains manuscrits [Desanges, 1980]. Le suffixe -ensis rend probable le substantif Chiniaua.

2 La confrontation du texte plinien et de l'épigraphe a suscité d'ardentes controverses qui portent sur le sens de l'expression oppidum ciuium Romanorum, sur la date de cette entité et de la liste du Naturaliste, sur la composition de l'ordo Chini[a]uensium peregrinorum, qui honorait, sous Commode ou sous Septime Sévère, son patron le Carthaginois Marcus Iulius Probatus Sabinianus. Les spécialistes sont encore divisés [Peyras, 1991]. Sommairement, nous remarquerons que ces oppida sont des groupements privés (conuentus ciuium Romanorum) pour L. Teutsch [1962] et B.D. Shaw [1981], des municipia ciuium Romanorum pour F. Vittinghof [1952] et J. Desanges [1972, 1980], un corps public (pagus, conventus,...) pour Ch. Saumagne [1965] et J. Gascou [1972]. Sans nous prononcer sur la signification de la locution, nous observerons qu'on ne saurait opposer à J. Desanges le mot peregrinorum pour refuser sa démonstration. Les peregrini ne sont pas ici les étrangers à la citoyenneté romaine, mais des incolae, c'est-àdire des étrangers résidents, attachés administrativement à la cité [Desanges, 1980].

Un fragment épigraphique, gravé sous Constantin le Grand ou son fils Constantin II sur un morceau d'architrave, est le dernier document que nous puissions verser au dossier de cette cité. Elle occupait entre Biha Bilta* et Vreu, $800 \mathrm{~m}$ d'ouest en est, $250 \mathrm{~m}$ du nord au sud, près d'un ruisseau, la chaaba Melk el Ouidane, qui débouche d'une cluse à $305 \mathrm{~m}$ d'altitude.

On distingue d'est en ouest :

- des haouanet et des fosses funéraires creusées dans le revers de la falaise.

- des sources qui alimentaient, à l'ouest, des thermes, près desquels gît un fragment de l'inscription C. 25450 .

- un grand édifice soigneusement construit en pierres de grand et moyen appareil. L'un des murs comprend 16 assises et a $4 \mathrm{~m}$ de haut. Devant l'édifice s'ouvre une esplanade 
jonchée de colonnes. Cet ensemble correspond probablement au capitole et au forum. - des aménagements hydrauliques qui ont permis, à l'Est, d'établir un barrage, un canal, deux bassins de réception, et une tour, appelée «terga » ( = le canal, en berbère) [Peyras, 1991].

5 Une dizaine de fermes et deux voies romaines, un tertre, un tumulus, ont été notés dans les environs de Chiniaua.

INDEX

Mots-clés : Antiquité, Linguistique, Tunisie, Ville 